\title{
Indonesia's Combat for Peace and Justice: A Bird's Eye View of Sustainable Development Goals (SDGS) 16
}

\author{
Wicipto Setiadi \\ \{wiciptos@gmail.com\}
}

Faculty of Law, Universitas Pembangunan Nasional Veteran Jakarta, Indonesia

\begin{abstract}
This paper aims to distinguish the current progress of SDG 16 implementation in Indonesia from a governance perspective and it's interconnectedness with Indonesia's past, present, and future technocratic plans. Although Goal 16 has numerous benefits to improve the quality of humanity and society itself, Indonesia has managed to synchronize, yet there are still critical dispute on how inclusive and progressive Goal 16 is when implemented in practice. The overall paper was based on desk and literary review from highlighting several standpoints on Goal 16 particularly on; a. Corruption and Bribery, b. Participatory Approach, and c. Institutional Building Capacity. Overall, in the implementation of SDGs Goal 16, there has been progressive achievement due to the collaboration of 4 stakeholders that reflect 'no one left behind' principle. Further, Indonesia commitment on actualizing SDGs is reflected on the participation of Voluntary National Review 2017. Surprisingly, Indonesia turns to be one of 6 countries that has outstanding best practice of compares to others. In the future, the commitment is continued to the mainstreaming all SDGs target into National Development Medium Plan (Rancangan Pembangunan Jangka Menengah/RPJMN 2020 - 2024). Though, there are still issues need to be settled, but with SDGs mainstreaming into RPJMN 2020 - 2024 hopefully the sustainability of the agenda is rest assured. The paper presented is based on literature reviews and documents relating to the subject at hand. From this research, systematic writing was produced using a juridical-analytical approach and qualitative results was obtained.
\end{abstract}

Keywords: Corruption; SDGs; Peace and Justice;

\section{Introduction}

On 2015 world leaders gather at the historic United Nation Summit to agree on the Sustainable Development Agenda. The prestigious agenda continues on 1 January 2016, when the world leaders agree to adopt the all 17 Sustainable Development Goals (SDGs) of the 2030 Agenda. The commitment under SDGs does not only reflect the interest of develop countries like most of other international treaties. Moreover it offers inclusive approach and method for developing countries as well, through its promising tagline 'no one left behind'. Taking into account the unfinished business of Millennium Development Goals (MDGs), the new goal of SDGs call the participation for every countries from high income, middle income, and lower income country to develop the world together into a prosperous place. In the millennium era, countries are getting familiar with the complexity of the current problem. In the case empowering economic sector, social issues including education, health, social protection, and 
job opportunities must also be addressed. The perplexity is getting real where climate change issue arises and becomes the global concern.

The support of SDGs towards developing country through 'no one left behind' principle is reflected on the participation of all stakeholders which are government and parliament, academia and experts, philanthropy and business associate, civil society organization and media. The involvement of multi stakeholder aims to create participatory and transparent platform for all particularly with the focus on the poorest, most vulnerable, and furthest behind. It is clear that the spirit of SDGs does not only become the government ambition since all parties are involved. It states that the ownership SDGs implementation is fully for all stakeholders.

In Indonesia, the government sees other stakeholders as strategic key counterparts. The principle of 'no one left behind' is internalized within all stages of SDGs implementation from the document preparation, formulation, implementation, and evaluation. First, the central government formulize National Action Plan (Rencana Aksi Nasional/RAN) as the baseline implementation within national scope. Second, the regional government develops Regional Action Plan (Rencana Aksi Daerah/RAD) as the foundation within regional coverage. Third, in order to strengthen SDGs, central government are currently in the process to finalized SDGs Roadmap. As for the RAN the total number of Non-State Actor involved are 108 which been progressive achievement. In addition currently, the total number of regional government which have formulized RAD are 18 Provinces.

Below are the list of Regional Government which has framed RAD and being actively participate towards SDGs implementation:

1. West Sumatera

2. Riau

3. South Sumatera

4. Bengkulu

5. Lampung

6. West Java

7. Central Java

8. Special Province of Yogyakarta

9. East Java

10. Bali

11. Nusa Tenggara Barat

12. Nusa Tenggara Timur

13. East Kalimantan

14. South Kalimantan

15. Central Sulawesi

16. South Sulawesi

17. North Sulawesi

18. Gorontalo

\section{The Power of Civic Engagement: A View of SDGs and OGP}

If we take a deeper look, SDGs and Open Government Partnership (OGP) actually poses the similar principle specifically on civic engagement. On the OGP Summit that was held in Georgia July $17-19,2018$ in Tbilisi. More than 2.200 attendees which includes government official, civil society organization, multilateral institution, private sector, academia, and think tank representing 115 countries committed to enforce government transparency. It is on that forum that the representation agrees on 3 key strategic issues as follow: 
1. Civic Engagement

2. Anti-Corruption

3. Public Service Delivery

Considering both OGP and SDGs, it presents new phenomenon of civil society's role and their contribution to the government which are getting more vital. It also conveys the message that the creation of good governance principle cannot be separated with the support of civil society organization (CSO). If the SDGs has included Non-State Actor on every stage of its implementation in Indonesia. Presently, OGP consider civic engagement as one parts of its action plan. Citizen involvement is needed to ensure that people have the opportunity to be involved in the preparation, implementation and supervision of development programs. However, this is only possible if people have a strong awareness of their rights as citizens. Further, the awareness and capability of the people must also be supported by a reachable system that can be easily accessed by them.

At this point the engagement of civic society is an integral aspect of good governance and transparency. The involvement of Non-State Actor mean to empower and stimulate them to understand and obtain their rights, so that they can give back the positive feedback for the community.

\section{Voluntary National Review 2017: Lesson Learned and Challenge for Indonesia}

In Indonesia development agenda, SDGs plays important roles as the mainstreaming merit. The vision is internalized and align with Nawa Cita and National Medium Term Development Plan (Rencana Pembangunan Jangka Menengah/RPJMN) 2015 - 2019. The close engagement of SDGs and RPJMN 2015 - 2019 set as basic principle to further define program, line Ministries, non-state actor, and most of importantly state budget (Anggaran Pendapatan dan Belanja Negara/APBN). Thus, by implementing SDGs it also means that the government actualizes the national development agenda.

Last 2017, was the first time for Indonesia to participate on Voluntary National Review (VNR) presented on High Level Political Forum. The forum open wide space for develop and developing countries to share their experience, challenge, as well as best practice on implementing SDGs. The theme for VNR SDGs 2017 is "Eradicating Poverty and Promoting Prosperity in a Changing World". VNR is a unique document since it shows the cross cutting and the interlinkage of each SDGs goals. On 2017, the VNR focuses on 7 goals as follow; Goal 1. End Poverty, Goal 2. End Hunger, Goal 3. Ensure Health and Well Being, Goal 5. Gender Equality, Goal 9. Infrastructure, Industry, and Innovation, Goal 14. Life below Waters, and Goal 17. Partnership. On its first debut to present the VNR together with other 43 countries, Indonesia was among the first country to send its report to United Nation.

Again on the preparation of VNR, the government applies the 'no one left behind' principle emphasizing transparency and participatory approach. On its formulation process, the 4 platforms are working side by side to discuss the issue. In order to strengthen the substance, periodical meetings and Focus Group Discussion been arranged for each goal. Further, to validate the quantitative aspect, the data used on were from $2006-2016$ collected from Central Statistical Agency (Badan Pusat Statistik/BPS), Ministries, CSO, Think Tank, and Universities. By the end, the result is widely share and can be easily accessed on www.sdgsindonesia.or.id.

In consideration the theme of $2017 \mathrm{VNR}$, the report focuses on 2 main aspects; 1. Improving the quality of human resource and 2. Enhancing economic opportunities for sustainable live hoods. Those 2 main focuses represent the interlinkage of 7 Goals within VNR 2019. In the case of improving human resource quality several goals matter. The 3 goals 
that are contributing most to build human capacity are Goal. 3 Health, Goal. 2 Food Security and Sustainable Agriculture, and Goal. 4 Education. Though, Goal 4. Education is not included within the theme of 2019 but a good education system is important to tackle poverty alleviation.

Additionally, improving economic opportunities is achieved by increasing the capacity of industry, innovation, and infrastructure (Goal.9) that will stimulate various economic sector and preserving marine ecosystem which also one of the challenge of Indonesia as archipelago country (Goal.14). In order to support the main focus, Goal 5. Gender and Goal. 17 Partnership, Data, and Sustainable Financing plays as the enabling factor. The integrated data base is vital aspect for a more effective target.

\section{Research Question}

What is the main challenge of SDGs 16's practice in Indonesia?

\section{Research Method}

This research is done by doing literature research, or commonly known as the literature study and uses the juridical approach method. Then the next approach used concept approach.

\section{Overview}

\subsection{Target Goal 16}

Following the mandate of Sustainable Development Goals (SDGs) that has been ratified as global commitment. Indonesia earnestly carries out the message of all 17 Goals either on national and regional scale. Moreover, progressive effort been done by the government which mainstreamed SDGs goals into National Mid Term Development Plan 2015 - 2019. In implementing SDGs, Indonesia government applies inclusive approach involving all stakeholders.

The paper highlights the efforts been carried out and the upcoming agenda on implementing SDGs particularly on Goal 16 'Peace, Justice, and Strong Institution'. The SDGs Goal 16 aims to promote peaceful and inclusive societies, provide access to justice for all, and build effective and inclusive institution at all levels. The goal has 12 main targets which are complementary to each other and covering essential element of justice. In short, the main message of SDGs 16 is to eliminate any form of violence and abuse, stop children exploitation, ensure access to justice for every individual, block any form of illicit financial and arm flow, reduce corruption and bribery, create transparent institution, engage public participation on policy making process, and encourage the participation of developing countries on international scale.

As for this paper, the analysis covers 3 specific targets which are, 1. Corruption and bribery, 2. Participatory approach on policy making process, and 3. Institutional building capacity on Violence, Terrorism, and Crime Prevention within international cooperation framework. In terms of corruption and bribery, Indonesia government gives specific attention not only to eradicate but most importantly to educate the people to have an anti-corruption character. 


\section{Anti-Corruption}

To take part of this action, Ministry of National Development Planning (Bappenas) coordinated the agenda of 'Corruption Prevention and Eradication' on 2015 - 2016. The program was implemented on both national and regional scope. Result shows considerable progress as reflected that on 2016 - 2017 that 80 Ministries/Agencies and 535 Regional Government involved. 'Corruption Prevention and Eradication' agenda on central government consists of 2 program which are Prevention and Law Enforcement. As for the following years, the main focus were similar but the sub program were slightly different.

The program mainly emphasizing on ensuring the implementation of e-government, regulatory reform, and the continuity of village fund realization. In the matter of corruption issue, it is important to build comprehensive national development plan to avoid the possible corruption act from the upstream. Initial study on corruption uncovers budget inefficiency arise mostly on planning and budgeting stage. Moreover, the anti-corruption agenda was implemented on regional scope concentrated on prevention aspect. The program composed of sub program which are, 1. Synergized license system of central and regional government, 2. E-Government, 3. Transparency procurement, and 4. License simplification.

In order to strengthen the anti-corruption agenda in Indonesia, the government established Anti-Corruption Index under the Central Statistical Agency. The index measures 2 aspects which are corruption based on perception and experience. There has been a declined score during 2017 - 2018 from 3.71 decrease into 3.66 out of 5.00. It reflects that the corruption is an urgent issue and people are relatively steer clear of it. Interestingly, people who live in town tend to have higher awareness of corruption compare to those who live in rural area. Statistic confirms that the index for townspeople is 3.81 and for those villagers is 3.47. Noting in this respect, the quality of education is a vital aspect to this index. Furthermore, people with good educational background relatively having good understanding of corruption issue and it is reflected on the index.

Presently, Indonesia's target on anti-corruption index is nowhere near the target of National Development Medium Plan 2015 - 2019 that supposed to raise into 4.00 by the end of 2019. Therefore, through the Government Annual Work Plan (Rencana Kerja Pemerintah) 2018 and 2019, the anti-corruption agenda is embedded into the sequence of planning and budgeting to assure its sustainability. Within the context of the Government Work Plan 2018, anti-corruption program takes place under the National Priority 10 'Politics, Law, Defense, and Security'. The effort is strengthen into 2019 under National Priority 5 'National Stability and Election Attainment'.

\section{Inclusive Participatory}

Delivering promising change cannot only be made one sided, the government has routinely involved several related stakeholders to partake in decision-making situations at needed times. Public participation are organized and held by the Ministry of Law and Human Rights, whereas Public Consultation Forum are organized and held by BAPPENAS. BAPPENAS annual forum invites participants to share their opinions, inputs, and suggestions on Indonesia's development for the upcoming Government Annual Work Plan. As stated under the Ministerial Decree No. 5/2018, article 8 paragraph 1 letter (a), the preparation of the initial draft on Government Annual Work Plan and its' funding must go through a public consultation meeting to capture the aspirations of development actors.

Indubitably, the implementation of the development process is carried out in an inclusive manner by involving public participation, therefore the government strives continuously to increase the public role in the process of formulating development policies, especially in the 
Government Annual Work Plan. The outcome is a compilation of public issues and recommendations relating to strategic issues on government national priorities and establishing coherent communication by implementing the forum as a bridge between the government and development stakeholders.

Furthermore, BAPPENAS's initiative alongside with UNDP had created Indonesia Democracy Index (IDI) to assess three aspects of democracy, namely civil liberties, political rights, and institutions democracy. This tool is expected to be useful to identify the strengths and weaknesses of democratic practices throughout the country. It is also a tool that is used for planning in the Government Mid Term Plan (RPJMN). The latest considerable progress is the positive increase from 70,09 in 2016 to 72,11 in 2017.

\section{Violence, Terrorism, and Crime Prevention}

Congruent steps are taken to hinder violence, combat terrorism and crime in Indonesia, specifically through Bappenas cooperation with UNODC under Country Programmed Strategy 2017 - 2020. After the launching ceremony that took place in November 222016 , on-going progress are taking place regarding the country's collaboration with UNODC. The program main focus is on Transnational Organized Crime and Illicit Trafficking, Anti-Corruption, Criminal Justice, and Drug Demand Reduction and HIV/AIDS.

Progress of the collaboration proceeded by holding a Mid Term Report in July 2018 at BAPPENAS. Relevant Ministries and Institutions work closely through the programs such as the Anti-Corruption Commission (KPK) who aligns their duty on Transnational Organized Crime's sub program to ensure that no individual are gaining profits in forest crime. For the program on Criminal Justice, the National Prevention and Terrorism Agency (BNPT) are in good agreement towards the workplan made as the program is aligned with their duty. Lastly, in the program on Drug Demand Reduction and HIV/AIDS, BNN's involvement with UNODC were still going strong. Evidently, Indonesia's international cooperation are serious when it comes to tackling on violence, terrorism, and crime.

Additionally, the Minimum Essential Force had an increase from 52,3\% in 2017 to 58,3\% in 2018. Law and Development Index (IPH) had a minimum increase from $0,57 \%$ in 2017 to $0,60 \%$ in 2017 . Key priorities are also included in The Government Annual Work Plan 2019 such as Security and Cyber Security, Success of General Elections, National Territory Defense, Legal Certainty and Bureaucracy Reformation, and Diplomacy Effectiveness, and also for 2020 for a chapter on its own on National Security Stability.

\subsection{Interlinkage of Goals}

\section{Linkage Goal 16 and Goal 5}

Indonesia's 2017 VNR on "Eradicating Poverty and Promoting Prosperity in a Changing World" places Goal 5 as one of the Enabling Environment that supports to "Improve Quality of Human Resources" and to "Enhance Economic Opportunity and Sustainable Livelihood" . Clearly, this shows how flexible and how widespread this goal is with the rest of the goals. Looking deeper into Gender Equality, it is not only a fundamental human right, but a necessary foundation for a peaceful, prosperous and sustainable world. Ending all forms of discrimination is not only a basic human right, but it also crucial to accelerating sustainable development. It has been proven time and again, that empowering women and girls has a multiplier effect, and helps drive up economic growth and development across the board. -So, to achieve these targets, Indonesia's government has plan. 
The implementation content of Law No. 7 In 1984, the government issued Presidential Instruction No. 9 of 2000 concerning Gender Mainstreaming (PUG) in National Development, which aims to organize planning, formulation, implementation, monitoring, and evaluation of national development policies and programs that are perspective in gender in order to realize gender equality and justice in Indonesia. In the national development planning sector, the context of gender mainstreaming has been one of the focus of policies as outlined in the 20152019 Medium-Term Government Work Plan (RPJMN), which is coordinated by BAPPENAS. Various ministries in Indonesia take crucial notice on tackling gender challenges and those that connects with it.

The Ministry of Women Empowerment and Child Protection has for significant programs that are specifically focus on women and children. Programs such as Increased Prevention and Handling of Various Violent Acts against Women, including Crimes in Trafficking in Person with Action Plan: Improving Women's Protection from Violence and has goal: Compilation of guidelines for the Guidelines for Improving Services for Women and Children Victims of Violence and : Increased Prevention and Handling of Various Violent Acts against Women, including Crimes in Trafficking in Persons, with Action Plan: Identifying the handling of victims of violence against women, and has goal: Availability of data handling victims of violence against women in 2014 aligns with SDG 5. The Social Ministry, Coordinating Ministry of Human Development and Culture, and Witness and Victim Protection Agencies all have the same outlook.

As what has been mentioned previously, Indonesia's Government takes SDGs seriously as reflects on National Action Plan to support the goal of SDG 5: Achieving Gender Equality and Empower All Women and Girls. Programs such as Child Protection Program held by Ministry of Women Empowerment and Child Protection \& Ministry of Women Empowerment and Child Protection, General Judicial Management Program held by Supreme Court of Republic of Indonesia, Education Program held by Ministry of Education and Culture, Population Program, Family Planning and Planned Parenthood held by The National Population and Family Planning Board (BKKBN), Informatic Development Program held by Ministry of Communication and Informatics, United Nation and Political Development Program held by Ministry of Home Affairs, and Management Support Program and technical task of Ministry of State Secretariat held by Witness and Victim Protection Institution are all part of the state Gender Mainstreaming implement in Institution.

From program and targets interconnects with Goal 16 which has 12 targets with 34 indicators which projected to be achieved by 2030, with 3 (three) main agenda: 1) remove all forms of violence. 2) Children Protection, 3) Handling Cases Related to Violence Against Woman, 4) Strengthening National legal guidance programs, 5) Improving the system of judicial administration, 6) Improving the registration system for the community, 7) Promote and protect human rights.

Regarding all the above statements, Indonesia has been progressing through the year with significant support from various ministries and agencies to take step to streamline Gender Mainstreaming (PUG). Gender Equality principles, policies and practices contribute directly to the substantive targets of the SDGs, specifically through Goal 5, and Goal 16 to strengthen Access to Justice. Indonesia's government already establish framework to any related stakeholder to be involved on the process of SDGs implementation and further to developing themself as reflects on National and Regional Action Plan. 


\section{Linkage Goal 16 and Goal 10}

Poverty is still one of the main challenge for Indonesia, substantial progress been made in poverty alleviation in the past 10 years from $17.75 \%$ (2006) - 10.70\% (2016). Although, the number of people living in poverty line is still 22.76 million people but the poverty gap among regions been narrowed. The rapid progress is due to comprehensive social protection system provided by the government through National Social Security System (Sistem Jaminan Sosial Nasional/SJSN) and social assistance. SJSN consists of 2 main program; National Health Insurance (Jaminan Kesehatan Nasional/JKN) and Indonesia Health Card (Kartu Indonesia Sehat/KIS). At the end of 2016, Indonesia population were 171.9 million people, and about the $40 \%$ of the population who have low income been covered by these facilities. In order to ensure that families with minimal wage have access to basic needs, on 2016 the beneficiaries expanded into 6 million poor families including pregnant woman, children under five, school age children, elderly, and people with disabilities.

The role of government to reach out those who are in need and vulnerable people proven to give significant impact on the decline of poverty rate. In this case, the constant decrease of poverty rate indirectly stimulates human capacity through good education and health system. Thus it can be seen that poverty cannot be lifted up just by providing basic needs, most importantly enhancing the capacity of people is mandatory so that they can give positive contribute back to the society.

The development of human capacity must be accompanied by economic opportunities. Industry, innovation, and infrastructure are one platform that be used to provide sustainable livelihoods through the creation of potential economic segment. As an archipelago country with more than 17.000 islands and which of two third of its area is ocean, no doubt that geographical barrier is still one of the issue the government faced off. There been a swift of infrastructure project, the priority of infrastructure project now targets the disadvantage, outermost, and frontier region aiming to reduce isolation and inequality. The strategy mainly aim to give effects on low income family to get more affordable prices and better opportunities on economic activity.

In the eastern region, 14 industrial park potentially absorb 962.800 workers, currently 3 industrial park been operated. The industrial strategy later on will focus on labor-intensive and local resource manufacturing that will absorb more manpower, enhance value added, provides more multiplier effect in the area. In this case, with potentially high number of worker involved it will contribute to poverty alleviation too.

\subsection{Challenge from the implementation of Goal 16}

The infamous challenge is the implementation practice itself in countries is no different in Indonesia as well. The SDG emphasize on inclusiveness, that all stakeholders are welcome. That both the Government and Non State Actors should intertwine to focus on the Goals. Although this idealism is perfect on paper, reality shows otherwise. It is difficult to measure what inclusiveness is and who is partaking what. As much as no one gets left behind, there is no indicator or participatory measurement as to who is left or who is involved.

Another challenge faced is how ambitious the target and indicators of Goal 16 "Promote peaceful and inclusive societies for sustainable development, provide access to justice for all and build effective, accountable and inclusive institutions at all levels.". Implementing and ending conflict once in for all sounds over optimistic. Taking a closer look at the target such as Target 16.2 "End abuse, exploitation, trafficking and all forms of violence against and torture of children", a 2030 deadline to end a crucial and on-going violence isn't likely to happen. Reasonably, to lessen, to decrease, or the reduction of the problem based on the 
indicators should be taken into account. Improvising is necessary, especially to each specific countries, yet on the global scale the baseline are the same targets and indicators.

The Ego-sectoral can also be a major problem implementing Goal 16 in Indonesia. This has been an on-going yet predictable problem for the country to let go of their own agenda and start focusing on the bigger goal. Ministries and Institutions has their own plans and certain programs, this can lead to a shaking accountability on the technocratic side with less strong bureaucracies. Lastly, Inconsistent data availability can also become an obstacle. For instance, for the VNR Report 2019, it is asked for the stakeholders to use a 10 years data. This can be difficult for Indonesia, especially when the Statistic Indonesia (BPS) had problems relating to its institution a few years ago causing less reliable data.

\section{Conclusion}

Initiatives are certainly being implemented and progress are taken place moderately. The involvement of key actors for the country's peace and justice will not only effect individually, but with consistency on implementing relevant policies aligning with the Annual Government Work Plan and the Government Mid Term Plan 2020 - 2024, achievement is thoroughly possible. The implementation of SDGs based on inclusive approach enrich the output. Together with philanthropies, CSOs, academia, and business associate, Indonesia government through BAPPENAS formulize a 'no one left behind' mechanism. All stakeholders in charged and involved from the preparation, realization, and monitoring evaluation. Further, the government will also invite the participation of Non-state Actor on the Voluntary National Review (VNR) 2019.

\section{References}

[1] The Sustainable Development Agenda, 17 Goals to Transform Our World, 2019, accessed on https://www.un.org/sustainabledevelopment/development-agenda/

[2] GA Resolution 70/1, para.74

[3] Stakeholders: Kementerian/Lembaga, Pemerintah Daerah, Filantropi dan Pelaku Usaha, Organisasi Masyarakat Sipil dan Media, Akademia dan Pakar, Tujuan Pembangunan Berkelanjutan, 2019, accessed on http://sdgs.bappenas.go.id/stakeholder/

[4] OGP Global Summit 2018, OGP Global Summit 2018: Tbilisi, 2019, accessed on https://www.opengovpartnership.org/events/ogp-global-summit-2018-tbilisi

[5] Voluntary National Review, High Level Political Forum 2017, accessed on https://sustainabledevelopment.un.org/hlpf/2017

[6] Voluntary National Review, High Level Political Forum 2017, accessed on https://sustainabledevelopment.un.org/hlpf/2017

[7] Voluntary National Review, High Level Political Forum 2017, accessed on https://sustainabledevelopment.un.org/hlpf/2017

[8] Sustainable Development Goals 16, Targets and Indicator, 2019, accessed on https://sustainabledevelopment.un.org/sdg16

[9] Monitoring System Portal, Presidential Staff Office, Corruption Prevention and Eradication Agenda 2015 - 2016, accessed on https://10.0.3.3/monitoring/index.php/core/index/74

[10] https://sirusa.bps.go.id/sirusa/index.php/dasar/pdf?kd=3522\&th=2017

[11] https://www.bps.go.id/pressrelease/2018/08/15/1534/indeks-demokrasi-indonesia--idi--tingkatnasional-2017-mengalami-peningkatan-dibandingkan-dengan-idi-nasional-2016.html

[12] https://www.bappenas.go.id/id/berita-dan-siaran-pers/pemerintah-indonesia-dan-unodcluncurkan-program-strategi-baru-untuk-indonesia-tahun-2017-2020/

[13] FKP Januari 2019 
[14] Presentation Minister of Bappenas on Indonesia's SDGs Voluntary National Review 2017, HLPF

[15] book of regulation of minister of national planning and development no. 7/2018

[16] https://www.brookings.edu/blog/future-development/2015/10/01/how-can-weimplement-sustainable-development-goal-16-on-institutions/ 